\title{
In vitro occurrence of dispersal fourth stage juveniles in Bursaphelenchus xylophilus co-incubated with Monochamus alternatus
}

\author{
Nobuo Ogura ${ }^{1}$ and Tadakazu Nakashima ${ }^{1}$
}

\begin{abstract}
The pinewood nematode (PWN), Bursaphelenchus xylophilus, was cultured on an unidentified fungus, which was related to Contortylenchus genitalicola, grown on potatoglucose-agar medium supplemented with yeast extract in a flattened culture bottle. C. genitalicola is an entomophagous and mycetophagous nematode parasitic to the Japanese pine sawyer, Monochamus alternatus. The mean number of dispersal 3rd stage juveniles $\left(\operatorname{DSJ}_{3} \mathrm{~s}\right)$ and the mean percentage of $\mathrm{DSJ}_{3}$ in the populations of PWN were 24, 870 and $93.1 \%$ at 80 days' culture. Dispersal 4th stage juveniles $\left(\mathrm{DSJ}_{4} \mathrm{~s}\right)$ developed in the culture bottles when $B$. xylophilus were co-incubated with pupa or adult $M$. alternatus on the fungus. $\mathrm{DSJ}_{4} \mathrm{~S}$ (mean number, 9,105) were recovered from 9-day-old $M$. alternatus adults that had been coincubated with B. xylophilus during the pupal and adult stages. The usual theory that occurrence of $\mathrm{DSJ}_{4}$ is triggered mainly by existence of Monochamus cerambycid pupa and adult has been supported by the in vitro experiment. Jpn. J. Nematol. 32 (2), 53-59 (2002).

Key words: the pinewood nematode, the Japanese pine sawyer, in vitro culture.
\end{abstract}

Hatched juveniles (2nd stage juveniles) of the pinewood nematode, Bursaphenchus xylophilus (Steiner et Buhrer) Nickle, have three developmental courses to adult stage (Mamiya, 1975); (1) Under conditions favorable for propagation, hatched juveniles develop into adults through propagative 3rd and 4th juvenile stages. (2) Under unfavorable conditions such as dry conditions, low temperature and lack of food, hatched juveniles develop into dispersal third stage juveniles $\left(\operatorname{DSJ}_{3} \mathrm{~s}\right)$. This stage has a round tail (Mamiya, 1975) and numerous lipid droplets within the body (Kondo and Ishibashi, 1978). The DSJ 3 molts to a propagative fourth stage juvenile then to an adult if it was given food such as Botrytis cinerea Pers. (3) $\mathrm{DSJ}_{3}$, in a certain case, molts to dispersal 4th stage juvenile (DSJ $\left.{ }_{4}\right)$. DSJ $\mathrm{DS}_{4}$ has a dome-shaped head and subcylindrical tail with a digitate terminus sharp tail and lack of stylet. DSJ $_{4}$ enters a cerambycid vector (Mamiya and Enda, 1972). It will molt to the adult stage under favorable conditions for propagation (Mamiya, 1975). The molt from $\mathrm{DSJ}_{3}$ to $\mathrm{DSJ}_{4}$ is triggered by the presence of cerambycid vector such as Monochamus carolinensis (Olivier) (Warren and Linits, 1993; Necibi and Linit, 1998) and M. alternatus Hope (Maehara and Futai, 1996). The molt appeared to be related to adult eclosion in $M$. carolinensis, and so the cue (s) from the cerambycid may be volatile chemicals (Necibi and Linit, 1998). In this paper, we tried in vitro induction of $\mathrm{DSJ}_{4}$ to obtain basic knowledge for developing bioassay method of the cue (s).

\section{MATERIALS AND METHODS}

${ }^{1}$ Forestry and Forest Products Research Institute, P. O. Box 16, Tsukuba Norin-danchi, Ibaraki 305-8687, Japan. 
B. xylophilus: T-4 strain isolated from dead Pinus densifrola Sieb. et Zucc. in Iwate prefecture, Japan (Kiyohara, Y., pers. comm.) were maintained on cultures of an unidentified fungus grown on $4 \mathrm{~cm}^{3}$ of potato-dextrose-agar (Pearlcore ${ }^{\circledR}$, Eiken Chemical, Japan) supplemented with yeast extract (Difco, USA) (YPDA) in culture bottles $(4.0 \times 7.5 \times$ height $2.5 \mathrm{~cm})$. The unidentified fungus was isolated from a dead juvenile of Contortylenchus genitalicola Kosaka and Ogura which is entomophagous and mycetophagous nematode parasitic to M. alternatus (Ogura and Kosaka, 1991; Kosaka and Ogura, 1993). The unidentified fungus clearly differs from known fungi isolated from pine trees and/or from M. alternatus and does not form spores on YPDA (Tabata, M., pers. comm.). The composition of YPDA was yeast extract $0.1 \%$, potato extract $0.4 \%$, glucose $2.0 \%$, agar $1.5 \%$ and distilled water (DW). The nematodes were isolated using both a sterilized Baermann funnel and sterilized DW and used for inoculum.

M. alternatus: Adults were captured in Ibaraki prefecture, Japan. Larvae were aseptically reared on artificial diet at $25 \pm 1^{\circ} \mathrm{C}$ under $16 \mathrm{~L}: 8 \mathrm{D}$ photoperiod (Kosaka and Ogura, 1990). Mature larvae were chilled at $7^{\circ} \mathrm{C}$ for over 3 months to break diapause and then used for experiments.

\section{Culture of $B$. xylophilus and occurrence of $\mathrm{DSJ}_{3}$}

Four $\mathrm{ml}$ of YPDA was poured into culture bottles, sealed with foam silicon plugs and autoclaved $\left(120^{\circ} \mathrm{C}, 15 \mathrm{~min}\right)$. A small block $(5 \times 5 \times 1.3 \mathrm{~mm})$ of the unidentified fungus-mycelia grown on YPDA was implanted onto YPDA in culture bottles. Three days after the implantation, a $20 \mu \mathrm{l}$ of nematode suspension containing ca. 1,000 B. xylophilus (mixture of larvae and adults) was dropped on the mycelia in the culture bottles. We feared that co-incubated $M$. alternatus was covered with medium during coincubation of B. xylophilus and M. alternatus in the following experiments. The cultures were, therefore, placed in desiccators $(30 \times 50 \times 30 \mathrm{~cm})$ to decrease moisture content of YPDA and cultured at $25 \pm 1{ }^{\circ} \mathrm{C}$. Approximate $3,000 \mathrm{~g}$ silica gel was placed in the desiccators to keep relative humidity below $10 \%$. Nematodes were isolated using the Baermann funnel method for $48 \mathrm{hr}$ at $25 \pm 1^{\circ} \mathrm{C}$ at $20,40,60,80$ and 100 days after inoculation. Number of replicates was 3 or 5 .

\section{Co-incubation of $B$. xylophilus and M. alternatus larva, pupa or adult}

Three pieces of thin pulp-tissue paper $(4.5 \times 6.6 \mathrm{~cm})$ that had been sterilized by autoclaving were placed on YPDA on which B. xylophilus had been cultured on mycelia of the unidentified fungus for 50 days. Post-diapause mature larvae, newly molted pupae or newly emerged adults of M. alternatus were individually placed on the tissue paper. Then the culture bottles were maintained in the desiccators at 25 $\pm 1^{\circ} \mathrm{C}$ for 10 days. Nematodes on the surface of the larvae, pupae and adults were washed away with DW. The DW, tissue paper and YPDA from a culture bottle were put together and the nematodes were isolated using the Baermann funnel method. Adults were cut into small pieces with scissors and then placed in the Baermann funnel to isolate nematodes.

\section{Co-incubation of $B$. xylophilus and M. alternatus during pupal and adult stage}

Newly molted pupae were individually put into culture bottles that contained 50-day-old cultures of B. xylophilus and 3 pieces of thin pulp-tissue paper. They were incubated at $25 \pm 1^{\circ} \mathrm{C}$ in the desiccators. Pupal periods were ca. 15 days. Newly formed adults remained in the culture bottles for $0,3,6,9$ or 12 days. Nematodes were isolated respectively from the adults and both tissue paper and YPDA using Baermann funnel. 


\section{Calculation of nemtode numbers}

Nematodes isolated using the Baermann technique were diluted with tap water to a final volume of 2,5 or $10 \mathrm{ml}$. The number of $\mathrm{DSJ}_{3} \mathrm{~s}, \mathrm{DSJ}_{4} \mathrm{~s}$, and other stage nematodes in each of four $30 \mu 1$ samples of the suspension was counted to estimate total numbers of the nematodes. Analysis of variance (ANOVA) and Tukey HSD multiple comparisons were performed using SYSTAT (SYSTAT Inc., USA). The analysis and comparisons of proportion of $\mathrm{DSJ}_{3} \mathrm{~S}$ in total nematodes were carried out using arcsine transformation of the datum.

\section{RESULTS}

\section{Culture of $B$. xylophilus and occurrence of $\mathrm{DSJ}_{3}$}

The mean number of surviving nematodes per culture bottle after 40 days culturing was 114,799 $(\mathrm{SD}=25,369)(\mathrm{n}=5)$, then gradually decreased (Fig. 1). Variances increased as days in culture increased. Some nematodes survived in all bottles until the 80th day of culture. YPDA in 2 out of 5 culture bottles were dried up at 100 days' culture and all nematodes within the bottles had died. The mean number of surviving nematodes was $6,213(\mathrm{n}=5, \mathrm{SD}=136,791)$ after the 100 days of culture. Mean numbers of $\mathrm{DSJ}_{3}$ per culture bottle at 40,60, 80 and 100 days were 33, $814(\mathrm{n}=5, \mathrm{SD}=10,746), 42,459$ ( $\mathrm{n}$ $=5, \mathrm{SD}=42,668), 24,869(\mathrm{n}=5, \mathrm{SD}=29,380)$ and $7,638(\mathrm{n}=3, \mathrm{SD}=13,077)$, respectively. The

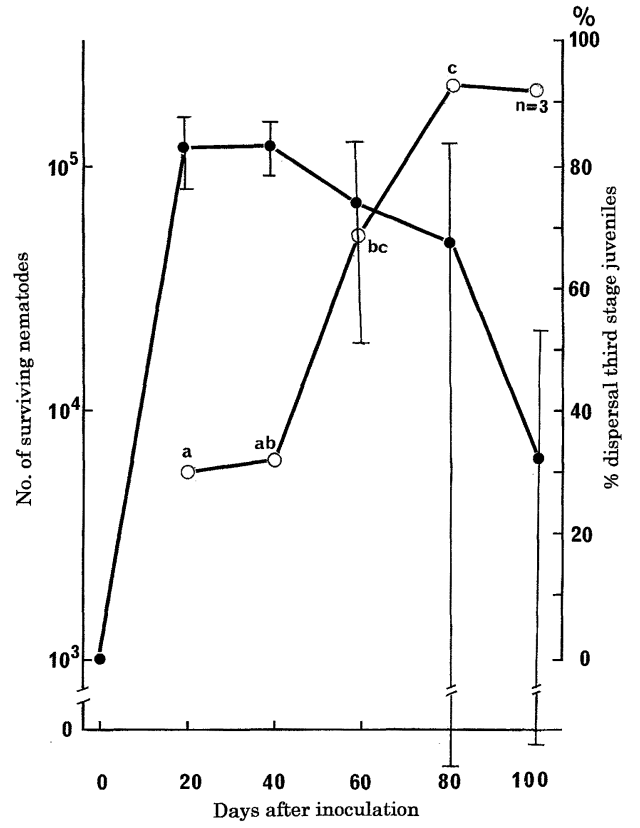

Fig. 1. Population change in cultures of Bursaphelenchus xylophilus on an unidentified fungus related to Contortylenchus genitalicola. Solid circle; Numbers of surviving nematodes (mean \pm SD) $(n=5)$ : Open circle; Percentage of dispersal third stage juveniles $\left(\mathrm{DSJ}_{3}\right)($ mean $\pm \mathrm{SD})(\mathrm{n}=5$ except an indication of $n=3$ ). Different letters in figure show a significant difference at $\mathrm{p}<0.05$ (Tukey HSD multiple comparisons).

Table 1. Numbers of Bursaphelenchus xylophilus $\mathrm{DSJ}_{3}$ and $\mathrm{DSJ}_{4}$ collected from culture bottles where Bursaphelenchus xylophilus and Monochamus alternatus were co-incubated for 10 days $(\mathrm{n}=7$ for each beetle life stage).

\begin{tabular}{|c|c|c|c|}
\hline Beetle treatment & $\begin{array}{l}\text { Nematode } \\
\text { life stage }\end{array}$ & $\operatorname{Mean}^{* * *}$ & $\mathrm{SD}$ \\
\hline \multirow[t]{2}{*}{ Mature larva } & $\mathrm{DSJ}_{3}^{*}$ & 117,982 & 19,301 \\
\hline & $\mathrm{DSJ}_{4}^{* *}$ & $158 \mathrm{ab}$ & 159 \\
\hline \multirow[t]{2}{*}{ Pupa } & $\mathrm{DSJ}_{3}$ & 102,304 & 8,826 \\
\hline & $\mathrm{DSJ}_{4}$ & $1,819 b c$ & 1,860 \\
\hline \multirow[t]{2}{*}{ Adult } & $\mathrm{DSJ}_{3}$ & 21,720 & 38,761 \\
\hline & $\mathrm{DSJ}_{4}$ & $3,218 \mathrm{c}$ & 2,736 \\
\hline \multirow[t]{2}{*}{ Control $^{* * * *}$} & $\mathrm{DSJ}_{3}$ & 104,884 & 24,820 \\
\hline & $\mathrm{DSJ}_{4}$ & $0 \mathrm{a}$ & 0 \\
\hline $\begin{array}{l}\text { Dispersal third-s } \\
\text { Dispersal fourth } \\
\text { Different letters } \\
\text { (Tukey HSD mu }\end{array}$ & $\begin{array}{l}\text { juvenile } \\
\text { ge juvenile } \\
\text { e compariso } \\
\text { e comifi }\end{array}$ & th difference & $\mathrm{p}<0.05$ \\
\hline
\end{tabular}


Table 2. Numbers of Bursaphelenchus xylophilus collected from culture bottles where B. xylophilus and Monochamus alternatus pupa and adult were coincubated ( $\mathrm{n}=5$ for each beetle life stage).

\begin{tabular}{lccc}
\hline \multicolumn{1}{c}{$\begin{array}{c}\text { Co-incubation } \\
\text { period }\end{array}$} & $\begin{array}{c}\text { Nematode } \\
\text { life stage }\end{array}$ & Mean & SD \\
\hline Pupal stage & $\mathrm{DSJ}_{3}^{* *}$ & $98,204 \mathrm{a}$ & 17,960 \\
+ adult stage 0 day & $\mathrm{DSJ}_{4}^{* *}$ & 995 & 1,068 \\
Pupal stage & $\mathrm{DSJ}_{3}$ & $56,705 \mathrm{ab}$ & 36,955 \\
+ adult stage 3 days & $\mathrm{DSJ}_{4}$ & 2,669 & 1,503 \\
Pupal stage & $\mathrm{DSJ}_{3}$ & $46,452 \mathrm{bc}$ & 33,305 \\
+ adult stage 6 days & $\mathrm{DSJ}_{4}$ & 13,402 & 11,059 \\
Pupal stage & $\mathrm{DSJ}_{3}$ & $29,586 \mathrm{bc}$ & 11,388 \\
+ adult stage 9 days & $\mathrm{DSJ}_{4}$ & 11,884 & 8,868 \\
Pupal stage & $\mathrm{DSJ}_{3}$ & $10,448 \mathrm{c}$ & 8,542 \\
+ adult stage 12 days & $\mathrm{DSJ}_{4}$ & 9,765 & 4,077 \\
\hline
\end{tabular}

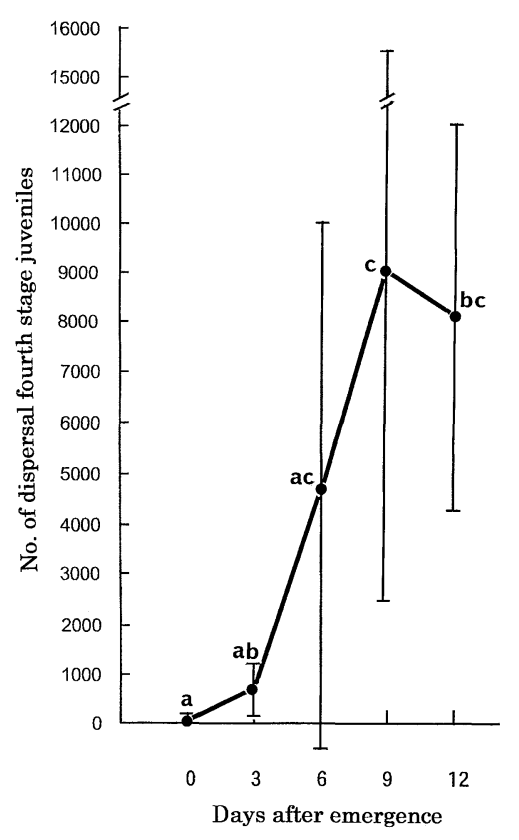

Fig. 2. Change in numbers of dispersal fourth stage juveniles $\left(\mathrm{DSJ}_{4} \mathrm{~s}\right)$ isolated from Monochamus alternatus adults (mean $\pm \mathrm{SD})(\mathrm{n}=5)$. Different letters in figure show a significant difference at $\mathrm{p}<0.05$ (Tukey HSD multiple comparisons).

percentage of DSJ ${ }_{3}$ increased as culture days increased. At 40,60, 80 and 100 days of culture, mean percentage of $\mathrm{DSJ}_{3}$ in total number of $B$. xylophilus in each culture bottle were $31.9(\mathrm{n}=5, \mathrm{SD}=14.2)$, $68.6(\mathrm{n}=5, \mathrm{SD}=38.8), 93.1(\mathrm{n}=5, \mathrm{SD}=50.9)$ and $92.8(\mathrm{n}=3, \mathrm{SD}=30.9)$, respectively.

\section{Co-incubation of $B$. xylophilus and $M$. alternatus larva, pupa or adult}

Mean numbers of DSJ 3 s and $\mathrm{DSJ}_{4} \mathrm{~s}$ recovered from the culture bottles, where B. xylophilus and larvae, pupae and adult of $M$. alternatus had been co-incubated, are showed in Table 1 . The mean numbers of $\operatorname{DSJ}_{4} \mathrm{~S}$ in culture bottles with larva, pupa and adult were 158, 1, 819 and 3,218, respectively. The mean number of $\mathrm{DSJ}_{4} \mathrm{~S}$ isolated from adults was 1,150 out of 3,218 . There was a stage-dependent difference in the number of $\mathrm{DSJ}_{4} \mathrm{~S}$ (ANOVA, factor: stage, $\mathrm{F}=5.9$, $\mathrm{df}=3,24 ; \mathrm{p}=0.004$ ). There was, however, no significant difference in the numbers of $\mathrm{DSJ}_{4} \mathrm{~S}$ in the culture bottles between larva and tissue paper-control (Tukey HSD, $\mathrm{p}=0.998$ ).

\section{Co-incubation of $B$. xylophilus and M. alternatus during pupal and adult stage}

The mean numbers of $\mathrm{DSJ}_{3} \mathrm{~S}$ and $\mathrm{DSJ}_{4} \mathrm{~S}$ recovered from cultures (M. alternatus adults, tissue paper and YPDA) at 0, 3, 6, 9 and 12 days after emergence are showed in Table 2. The range in both $\mathrm{DSJ}_{3}$ and $\mathrm{DSJ}_{4}$ numbers was very large. There was an incubation period-dependent difference in the numbers of $\mathrm{DSJ}_{3}$ (ANOVA, factor: incubation period, $\mathrm{F}=10.8, \mathrm{df}=4,20 ; \mathrm{p}=0.000$ ). The numbers decreased as the incubation period increased. There was no incubation period-dependent difference in the numbers of $\mathrm{DSJ}_{4} \mathrm{~S}$ (ANOVA, factor: incubation period, $\mathrm{F}=2.8, \mathrm{df}=4,20 ; \mathrm{p}=0.052$ ). The mean numbers of $\mathrm{DSJ}_{4} \mathrm{~s}$ 
isolated from adult beetles at 9 and 12 days after emergence were $9,105(\mathrm{SD}=6,553)$ and 8, $208(\mathrm{SD}=$ 3757), respectively. These were significantly greater than at 0 day (mean number; $995, \mathrm{SD} ; 1,068$ ) (Tukey HSD, $\mathrm{p}<0.05$ ). The mean numbers of $\mathrm{DSJ}_{4} \mathrm{~s}$ at 9 days was larger than ones at 0 and 3 days (Tukey HSD, $\mathrm{p}=0.031$ ) (Fig. 2) .

\section{DISCUSSION}

The proportion of $\mathrm{DSJ}_{3} \mathrm{~S}$ in the total nematode population increased as moisture content decreased in pine seedlings (Suzuki and Kiyohara, 1978) and in pine chips (Tomminen et al., 1991). A similar trend, although not statistically significant, was shown in pine bolts in which Ophiostoma minus (Hedgcock) H. et P. Sydow, B. xylophilus and M. carolinensis were co-incubated (Warren and Linit, 1993). Correlation between moisture content and the percentage of $\mathrm{DSJ}_{3}$ to total nematodes, however, was not found in pine bolts into which Trichoderma sp. and B. xylophilus had been inoculated (Maehara and Futai, 1996). Ishibashi and Kondo (1977) cultured 10 female and 10 male adults of B. xylophilus on Botrytis cinerea in test tubes $(18 \times 180 \mathrm{~mm})$ containing $10 \mathrm{ml}$ potato-sucrose-agar medium at $20^{\circ} \mathrm{C}$ without humidity control. In their experiment, the nematode population reached ca. $1 \times 10^{5}$ after 30 days and then decreased to $10^{2}$ after 180 days. $\mathrm{DSJ}_{3}$ began to appear after 90 days and constituted more than $95 \%$ of the surviving population (less than $10^{3}$ ) after 270 days.

We placed cultures in a desiccator to decrease moisture content of YPDA to prevent co-incubated $M$. alternatus from being covered with medium. We obtained ca. $1 \times 10^{4}-1 \times 10^{5} \mathrm{DSJ}_{3}$ s per culture bottle after 80 days' culture when $M$. alternatus was not co-incubated. Nevertheless, YPDA in culture bottles with $M$. alternatus adult was bitten and trampled down by the adult. This may be one of the reasons that numbers of $\mathrm{DSJ}_{3} \mathrm{~S}$ isolated from cultures with the adult decreased as incubation periods prolonged. The other reasons for decrease in numbers of $\mathrm{DSJ}_{3} \mathrm{~S}$ is occurrence of $\mathrm{DSJ}_{4}$ and may be death due to failure of molting from $\mathrm{DSJ}_{3}$ to $\mathrm{DSJ}_{4}$. It was not obvious whether or not the dry condition was good for in vitro increase of $\mathrm{DSJ}_{3} \mathrm{~s}$.

Ishibashi and Kondo (1977) showed that proportion of $\mathrm{DSJ}_{4} \mathrm{~S}$ to B. xylophilus juveniles collected from the pupal chambers with full grown larval, early pupal, mid-pupal, late pupal and adult M. alternatus individual were $11.5,29.6,84.0,97.5$ and $98.8 \%$, respectively. They suggested that the molt from $\mathrm{DSJ}_{3}$ to $\mathrm{DSJ}_{4}$ might be induced by the non-residual matter emitted from the pupating M. alternatus. In co-incubation ( 60 to 70 days) of B. xylophilus and M. carolinensis using pine bolts ( $40 \mathrm{~cm}$ long) infested with $O$. minus, mean numbers of $\mathrm{DSJ}_{4} \mathrm{~S}$ recovered from larvae, pupae and teneral (callow) adults were 25. 3, 1, 619.5 and 6, 858.4, respectively (Warren and Linit, 1993). DSJ $\mathrm{S}_{4}$ occurred and boarded M. alternatus adults in co-incubation of B. xylophilus and M. alternatus using small pine wood blocks ( $25 \times$ $25 \times 50 \mathrm{~mm}$ ) in which Trichoderma spp. or O. minus had been inoculated (Maehara and Futai, 1996). They demonstrated that $M$. alternatus was essential for the occurrence of $\mathrm{DSJ}_{4}$. Almost similar results were obtained from co-incubation of B. xylophilus and M. alternatus, using small pine bolts (75 mm long) infested with O. minus (Aikawa et al., 1997; Aikawa and Togashi, 1997). Forty-eight hr coincubation of B. xylophilus and M. carolinensis in artificial galleries made in pine disks $(7 \mathrm{~cm}$ thick) in which $\mathrm{DSJ}_{3} \mathrm{~S}$ had been present showed that $\mathrm{DSJ}_{4} \mathrm{~S}$ were recovered from early pupae, late pupae, callow adults and adults but not from larvae (Necibi and Linit, 1998). They proposed that a genus-specific substance (s) associated with Monochamus adult eclosion trigger the $\mathrm{DSJ}_{3}$ to $\mathrm{DSJ}_{4}$ molt. In the present 10 days' in vitro co-incubation of B. xylophilus and M. alternatus, numbers of $\mathrm{DSJ}_{4} \mathrm{~S}$ were large when co- 
incubated with adults and to a lesser extent with pupae. $\mathrm{DSJ}_{4} \mathrm{~S}$ also appeared in co-incubation with fullgrown larvae, though there was no significant difference between the numbers and ones in control. This indicates that $M$. alternatus pupa and adult affect occurrence of $\mathrm{DSJ}_{4}$ and also that even larva may have the same effect if co-incubation period is very long. When $\mathrm{DSJ}_{4} \mathrm{~S}$ recovered from $M$. alternatus adults were kept on $1.0 \%$ water agar at $20^{\circ} \mathrm{C}, 12.5 \%$ of the $\mathrm{DSJ}_{4} \mathrm{~s}$ survived for 100 days (Ishibashi and Kondo, 1977). The pupal period of $M$. alternatus at $20^{\circ} \mathrm{C}$ was approximately 20 days (Enda, 1976). Therefore, a part of $\mathrm{DSJ}_{4} \mathrm{~S}$ that occurred beside $M$. alternatus larvae may reside on the adults developing from the larvae.

Occurrences of $\mathrm{DSJ}_{4}$ under insect-free condition were observed in wood chips (Tomminen et al., 1991) and in culture of B. xylophilus on B. cinerea growing on potato-glucose-agar medium supplemented with glycerol (Kiyohara and Bolla, 1990). In this paper, none of DSJ $_{4}$ was isolated from cultures without $M$. alternatus.

We conclude that occurrence of $\mathrm{DSJ}_{4}$ is triggered mainly by existence of Monochamus cerambycid pupa and adult as Necibi and Linit (1998) indicated.

\section{ACKNOLEDGEMENT}

We thank Prof. M. J. Linit, University of Missouri-Columbia, for reviewing an earlier version of the manuscript.

\section{LITERATURE CITED}

Aikawa, T., Maehara, N., Futai, K. and Togashi, K. (1997) A simple method for loading adult Monochamus alternatus (Coleoptera: Cerambycidae) with Bursaphelenchus xylophilus (Nematoda: Aphelenchoididae). Applied Entomology and Zoology 32, 341-346.

Aikawa, T. and Togashi, K. (1997) An effect of inoculum quantity of Bursaphelenchus xylophilus (Nematodal Aphelenchoididae) on the nematode load of Monochamus alternatus (Coleoptera: Cerambycida) in laboratory. Japanese Jounal of Nematology 27, 14-21.

Enda, N. (1976) Life cycle of the Japanese pine sawyer, Monochamus alternatus. Forest Pest 25, 182-185. (in Japanese)

Ishibashi, N. and Kondo, E. (1977) Occurrence and survival of the dispersal forms of pine wood nematode, Bursaphelenchus lignicolus Mamiya and Kiyohara. Applied Entomology and Zoology 12, 293-302.

Kiyohara, T. and Bolla, R. I. (1990) Pathogenic variability among populations of the pinewood nematode, Bursaphelenchus xylophilus. Forest Science 36, 1061-1076.

Kondo, E. and Ishibashi, N. (1978) Ultrastructural differences between the propagative and dispersal forms in pine wood nematode, Bursaphelenchus lignicolus, with reference to survival. Applied Entomology and Zoology 13, 1-11.

Kosaka, H. and Ogura, N. (1990) Rearing of the Japanese pine sawyer, Monochamus alternatus (Coleoptera: Cerambycidae) on artificial diets. Applied Entomology and Zoology 25, 532-534.

Kosaka, H. and Ogura, N. (1993) Contortylenchus genitalicola n. sp. (Tylenchida: Allantonematidae) from the Japanese pine sawyer, Monochamus alternatus (Coleoptera: Cerambycidae). Applied Entomology and Zoology 28, 423-432.

Maehara, N. and Futai, K. (1996) Factors affecting both the numbers of the pinewood nematode, Bursaphe- 
lenchus xylophilus (Nematoda: Aphelenchoididae), carried by the Japanese pine sawyer, Monochamus alternatus (Coleoptera: Cerambycidae), and the nematode's life history. Applied Entomology and Zoology 31, 443-452.

Mamiya, Y. (1975) The life history of the pine wood nematode, Bursaphelenchus lignicolus. Japanese Journal of Nematology 5, 16-25. (in Japanese with English summary)

Mamiya, Y. and Enda, N. (1972) Transmission of Bursaphelenchus lignicolus (Nematoda; Aphelenchoididae) by Monochamus alternatus (Coleoptera: Cerambycidae). Nematologica 18, 159-162.

Necibi, S. and Linit, M. J. (1998) Effect of Monochamus carolinensis on Bursaphelenchus xylophilus dispersal stage formation. Journal of Nematology 30, 246-254.

Ogura, N. and Kosaka, H. (1991) Biology of a tylenchid nematode parasitic on the Japanese pine sawyer, Monochamus alternatus. Nematologica 37, 455-469.

Suzuki, K. and Kiyohara, T. (1978) Influence of water stress on development of pine wilting disease caused by Bursaphelenchus lignicolus. European Journal of Forest Pathology 8, 97-107.

Tomminen, J., Halik, S. and Berglahl, D. R. (1991) Incubation temperature and time effects on life stages of Bursaphelenchus xylophilus in wood chips. Journal of Nematology 23, 477-484.

Warren, J. E. and Linit, M. J. (1993) Effect of Monochamus carolinensis on the life history of the pinewood nematode, Bursaphelenchus xylophilus. Journal of Nematology 25, 703-709.

Received September 11, 2002.

\title{
和文摘要
}

\section{平底角型培養瓶を用いたマツノザイセンチュウとマツノマダラカミキリ の共存培養と分散型 $\mathrm{IV}$ 期幼虫の生起}

\author{
小倉 信夫 ·中島 忠一
}

平底角型培養瓶を用いて、酵母抽出物を添加したPDA 培地上で Contortylenchus genitalicola (マツノマダラカミキリの生殖器に寄生する菌食性昆虫寄生線虫）関連の未同定菌とマツノザ イセンチュウを培養した。80日間の培養では、分散型而期幼虫の培養瓶当たりの平均頭数は 24,869 頭で、分散型 III 期幼虫の全線虫頭数に占める割合の平均は93.1\%であった。この未同定 菌とマツノザイセンチュウを培養した平底角型培養瓶にマツノマダラカミキリの蛹あるいは成 虫を入れて共存培養すると、分散型 $\mathrm{N}$ 期幼虫が生じ、その頭数は対照区と有意な差があった。 全蛹期間と成虫期の 9 日間をマツノザイセンチュウと共存培養したマツノマダラカミキリ成虫 からは、平均 9,105 頭の分散型 $\mathrm{I}$ 期幼虫が分離された。分散型 $\mathrm{V}$ 期幼虫の生起には Monochamus 属カミキリの蛹および成虫が関わっているという従来の説は、培養瓶を用いた実験でも支持さ れた。 